\title{
Agro-metrological investigation of bumper apple productivity in Himachal Pradesh, India
}

\author{
Ranbir Singh Rana ${ }^{1}$, Manmohan Singh ${ }^{2}, \operatorname{Ramesh}^{1}$, Aditya $^{3}$ and Ranu Pathania ${ }^{4}$ \\ ${ }^{1}$ Centre for Geo- Informatics Research and Training, Chaudhary Sarwan Kumar Himachal Pradesh Agricultural \\ University, Palampur- 176062 (Himachal Pradesh), INDIA \\ ${ }^{2}$ Meteorological Centre, Shimla-171001 (Himachal Pradesh), INDIA \\ ${ }^{3}$ Department of Environmental Sciences, Dr. Y. S. Parmar University of Horticulture \& Forestry, Solan-173212 \\ (Himachal Pradesh), INDIA \\ ${ }^{4}$ Department of Agronomy, Chaudhary Sarwan Kumar Himachal Pradesh Agricultural University, Palampur- \\ 176062 (Himachal Pradesh), INDIA \\ *Corresponding author: E-mail: ranars66@gmail.com
}

Received: May 6, 2015; Revised received: September 6, 2015; Accepted: February 3, 2016

Abstract: The study aimed to investigate the productivity and weather relationship for the apple growing areas of Himachal Pradesh viz., Kalpa, Bhuntar and Shimla in district Kinnaur, Kullu and Shimla, respectively. The results revealed that pre bloom period (November to February) in the year 2009-10 remained cooler. The minimum temperature of 0.4 to $0.9,1.0$ to $1.1^{\circ} \mathrm{C}$ and 1.9 to $2.2^{\circ} \mathrm{C}$ and maximum temperature of $6.7,1.0$ to 1.1 and $1.7^{\circ} \mathrm{C}$ were lower in Shimla, Bhuntar and Kalpa region, respectively compared to 1995-2009.. The maximum temperature for the chill accumulation months of November, December, January and February during 2009-10 showed 13 to 19 per cent lower compared to 1995-2009. The average pre bloom rainfall during 2010 was 39 to 57 per cent higher than 19952009 indicating sustainable bloom period. The 3 to $4^{\circ} \mathrm{C}$ temperature rise during March $2010\left(19\right.$ to $\left.24^{\circ} \mathrm{C}\right)$ as compared to $1995-2009\left(16\right.$ to $\left.21.4^{\circ} \mathrm{C}\right)$ coupled with 52 per cent higher precipitation benefited the crop in profuse flowering and hence good fruit set. The average maximum temperature during the post bloom period (May-June) in 200910 was $1^{\circ} \mathrm{C}$ higher compared to the previous years coupled with 23 per cent higher rainfall resulting in an highest productivity. The highest productivity (8.57 MT/ha) during 2010 which was 58 per cent higher than the previous years can be ascribed due to the favorable low temperature in pre bloom period and increase in the temperature in the month of March along with adequate rainfall in the bloom and post bloom period.

Keywords: Apple, Flowering, Precipitation, Productivity, Temperature

\section{INTRODUCTION}

Apple (Malus domestica) is the major fruit crop of the state occupying about 49 per cent of the total area under fruits and 72 per cent of total area under temperate fruits, contributing about 85 per cent of total fruit production in the state (Anonymous, 2015). Area under apple as well as that under total fruits increased over time and total apple production has also increased at the rate of 9.15 per cent per annum (Anonymous, 2009). Climatic conditions viz., temperature and water availability are important signals controlling the active growth of the crop and therefore, affect the final production. Climate not only limits for growth of a crop but also determines to a great degree the consistency of productivity and the quality. Therefore, changes in long term environmental conditions can have enormous impacts on plant diversity patterns and deleterious effects on human systems. Climate change has many facets including changes in long term trends in temperature and rainfall regimes as well as year to year variability. With the change in the average climatic variables as is evident during the past few decades, the productivity of the fruits in the state has also influenced. The decreased productivity of apple orchards in the recent years due to change in climatic conditions has become a serious concern of the growers in Himachal Pradesh. Due to the erratic weather conditions, some parts of state dominated by apple were now falling low in terms of being commercially productive (Vedwan, 2006). Extending and fully integrating the knowledge of climate and weather can optimize agricultural production with maximum use of weather resources and minimal damage to environment. The year 2010 witnessed the highest productivity attained in the past 15 years due to the favourable climatic conditions. Therefore, the present study was envisioned to see the cause of highest apple productivity in relation to the weather parameters.

\section{MATERIALS AND METHODS}

The study area included the three sites in apple growing districts of Himachal Pradesh viz., Bhuntar in 
Kullu district (1200-2500 m above mean sea level), Shimla in Shimla District (2200-3250 m above mean sea level) and Kalpa in Kinnaur district (2300-6800 m above mean sea level) representing different elevations with large area under apple cultivation (Fig.1). The weather parameters affect apple crop at the different stages from dormant to maturing stage. The weather parameters such as maximum temperature, minimum temperature and precipitation for the period of 1995 to 2010 for the months of November to June were analysed. The weather data collected from Meteorological Centre, Shimla was divided into pre bloom period (November to February) essential for chill accumulation, bloom period (March to April) and post bloom period (May to June) which determines the fruit set. The trends for each parameter were computed using fortnight mean values on seasonal scale. The weather data of year 2009-10 was compared with the average data for period 1995-2009 to evaluate the magnitude of change in climatic factors vis-à-vis productivity. The apple area and production data of 1995-2010 for the three study sites and overall productivity data of Himachal Pradesh was taken from the State Horticulture Department, Shimla and the productivity trends for the past 15 years were analyzed. The weather data for the study sites was averaged to represent the average weather of Himachal Pradesh as these sites are the main apple producing areas from different districts of Himachal Pradesh. Correlation between productivity

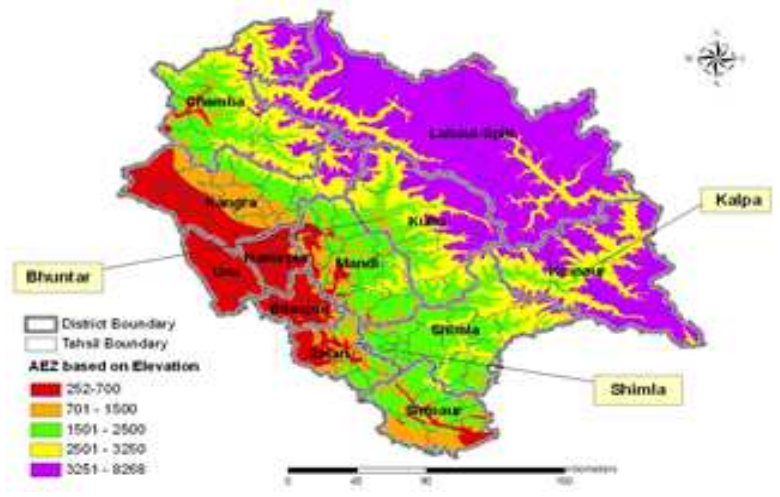

Fig. 1 Study sites representing different agro climatic conditions of Himachal Pradesh.

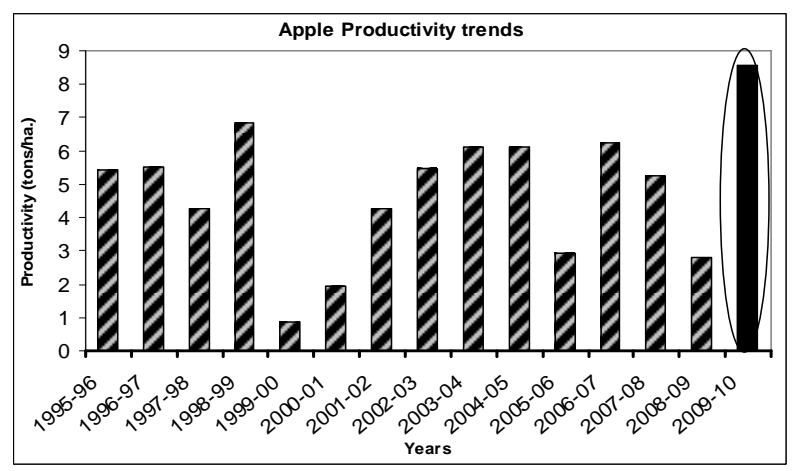

Fig.2 Apple productivity trends in Himachal Pradesh (1995-2010). and various weather parameters was also worked out using standard procedure.

\section{RESULTS AND DISCUSSION}

The apple productivity data depicted in Fig. 2 indicated that the year 2010 was the best crop year in past 15 years with highest productivity of $8.57 \mathrm{MT} / \mathrm{ha}$ which was 58 per cent higher as compared to mean productivity of 1995-2009. The analysis of weather data revealed an increasing trend in maximum and minimum temperature and an irregularity in precipitation pattern over the years.

Climatic element trends in different apple growing regions

Shimla region (District Shimla): The average mean temperature of the region touched a minimum of $3.4^{\circ} \mathrm{C}$ whereas maximum temperature went up to $25.5^{\circ} \mathrm{C}$ during 1995-2009. The annual average rainfall for the duration of 1995-2009 varied from 4880 to $13890 \mathrm{~mm}$. In the year 2009-10, maximum temperature (15.5 to $16.6^{\circ} \mathrm{C}$ ) showed a decrease of the order of $3-4^{\circ} \mathrm{C}$ compared to the mean value of 1995-2009 period during the months of November to February (pre bloom period) which are essential for a good chill accumulation (Fig. 3a). A decline of $6.7^{\circ} \mathrm{C}$ in December month was further noticed in maximum temperature of 2009-10. The minimum temperature also showed a decline of 0.4 to $0.9^{\circ} \mathrm{C}$ during November and December and a lower magnitude of 0.1 to $0.8^{\circ} \mathrm{C}$ in the pre bloom period in the year 2009-10 (Fig. 3b) compared to 19952009. The temperature started rising to a favorable range $\left(16\right.$ to $\left.19^{\circ} \mathrm{C}\right)$ during the month of March to April (bloom period) ( 3 to $4^{\circ} \mathrm{C}$ higher) which was helpful for the induction of dormancy and ensuring plentiful flowering in apple. The apposite temperature condition was further benefited by the rainfall (150.0 to $243.0 \mathrm{~mm}$ ) which was 25 per cent higher during the bloom period (Fig. 3c) and 35.1 per cent higher in January month than the period of 1995-2009. Singh et al. (2009) also concluded that pre bloom and bloom temperature up to $20^{\circ} \mathrm{C}$ and $150-200 \mathrm{~mm}$ precipitation is most beneficial for chilling and flowering in apple crop. Though the temperature in Shimla region during the post bloom period (May to June) in 2009-10 remained 0.7 to $1.5^{\circ} \mathrm{C}$ higher $\left(24.7\right.$ to $\left.26.5^{\circ} \mathrm{C}\right)$ as compared to $1995-2009$ period $\left(24\right.$ to $\left.25^{\circ} \mathrm{C}\right)$ but was accompanied by $458.0 \mathrm{~mm}$ rainfall which was 54 per cent higher compared to 1995-2009 and hence a good fruit set was obtained in 2009-10. The highest productivity (22.8 MT/ha) for the Shimla region in the year 2009-10 (Table 1) can thus be attributed to the favorable climatic conditions during the year.

Bhuntar region (District Kullu): The perusal of climatic data indicated that the mean annual maximum temperature of the region remained between 16.7 to $32.7^{\circ} \mathrm{C}$ in the period $1995-2009$ which was 0.8 to $2.0^{\circ} \mathrm{C}$ higher than 2009-10. Aditya et al., (2012) revealed from the study conducted at Kullu district of Himachal Pradesh that the decrease in chill units due to 
an increase in temperature adversely affected the apple productivity in past and half decade. The analysis indicated that the maximum temperature during the chill accumulation period (November to February) in the year 2009-10 remained in a range of 16.1 to $20.1^{\circ} \mathrm{C}$ (Fig. 3d) which was 3 to $5^{\circ} \mathrm{C}$ lower and 1.0 to $1.1^{\circ} \mathrm{C}$ lower in November and December and minimum temperature $\left(1.1\right.$ to $\left.5.9^{\circ} \mathrm{C}\right)$ was found to be 0.3 to $1.0^{\circ} \mathrm{C}$ lower than the pre bloom period of 1995-2009 (2.1 to $6.1^{\circ} \mathrm{C}$ ) (Fig. 3e). The minimum pre bloom temperature ranged between 1.0 and $6.0{ }^{\circ} \mathrm{C}$ contributes maximum to the chilling requirement of apple (Byrne and Bacon, 1992). The congenial winter temperature along with a precipitation of $173.6 \mathrm{~mm}$ (91 per cent higher) in the February month of 2009-10 resulted in completion of chill requirement. The rainfall amount of 40.6 and $56.8 \mathrm{~mm}$ in November and February was higher during 2009-10 as compared 1995-2009. The further rise of temperature 2.0 to $3.0{ }^{\circ} \mathrm{C}$ during the month of March 2010 followed by 86 per cent higher rainfall (78.0 to $515.0 \mathrm{~mm}$ ) (Fig. 3f) ensured good flowering and the fruit set. The mild summer season in 2009-10 with minimum temperature remaining below $18^{\circ} \mathrm{C}$ and 31 percent higher rainfall (193.0 to $599.0 \mathrm{~mm}$ ) as compared to 1995-2009 resulted in a good fruit set. Awasthi (2006) in his study on temperate fruits observed that most favorable temperature for fruit set in apple is $15-22^{\circ} \mathrm{C}$. Thus the optimal weather during the year 2009-10 resulted in the highest productivity of Bhuntar region (9.69 MT/ha) than the previous years

Table 1. Productivity (MT/ha) of apple in different apple growing sites of Himachal Pradesh (1995-2010).

\begin{tabular}{cccc}
\hline Year & Shimla & Bhuntar & Kalpa \\
\hline $1995-96$ & 12.2 & 4.17 & 4.28 \\
$1996-97$ & 7.00 & 4.55 & 5.71 \\
$1997-98$ & 13.4 & 6.26 & 4.11 \\
$1998-99$ & 1.20 & 0.46 & 1.90 \\
$1999-00$ & 16.6 & 4.13 & 5.21 \\
$2000-01$ & 6.10 & 1.99 & 4.36 \\
$2001-02$ & 11.9 & 5.19 & 4.93 \\
$2002-03$ & 14.4 & 6.12 & 4.08 \\
$2003-04$ & 14.8 & 8.43 & 7.56 \\
$2004-05$ & 13.7 & 8.04 & 7.81 \\
$2005-06$ & 7.00 & 2.44 & 7.38 \\
$2006-07$ & 14.4 & 8.65 & 7.48 \\
$2007-08$ & 13.4 & 4.08 & 9.52 \\
$2008-09$ & 6.7 & 2.81 & 6.47 \\
$2009-10$ & 22.8 & 9.69 & 10.03 \\
\hline
\end{tabular}

Table 2. Increase/decrease in apple productivity (per cent) in Himachal Pradesh (1995-2010).

\begin{tabular}{|c|c|c|}
\hline Year & Productivity (MT/ha) & $\begin{array}{c}\text { Increase/decrease in productivity (per } \\
\text { centage) }\end{array}$ \\
\hline $1995-96$ & 5.41 & 0 \\
\hline 1996-97 & 5.50 & 2 \\
\hline $1997-98$ & 4.26 & -21 \\
\hline 1998-99 & 6.85 & 27 \\
\hline 1999-00 & 0.88 & -84 \\
\hline $2000-01$ & 1.94 & -64 \\
\hline 2001-02 & 4.26 & -21 \\
\hline $2002-03$ & 5.46 & 1 \\
\hline $2003-04$ & 6.12 & 13 \\
\hline 2004-05 & 6.10 & 13 \\
\hline $2005-06$ & 2.92 & -46 \\
\hline $2006-07$ & 6.26 & 16 \\
\hline 2007-08 & 5.24 & -3 \\
\hline 2008-09 & 2.81 & -48 \\
\hline $2009-10$ & 8.57 & 58 \\
\hline
\end{tabular}



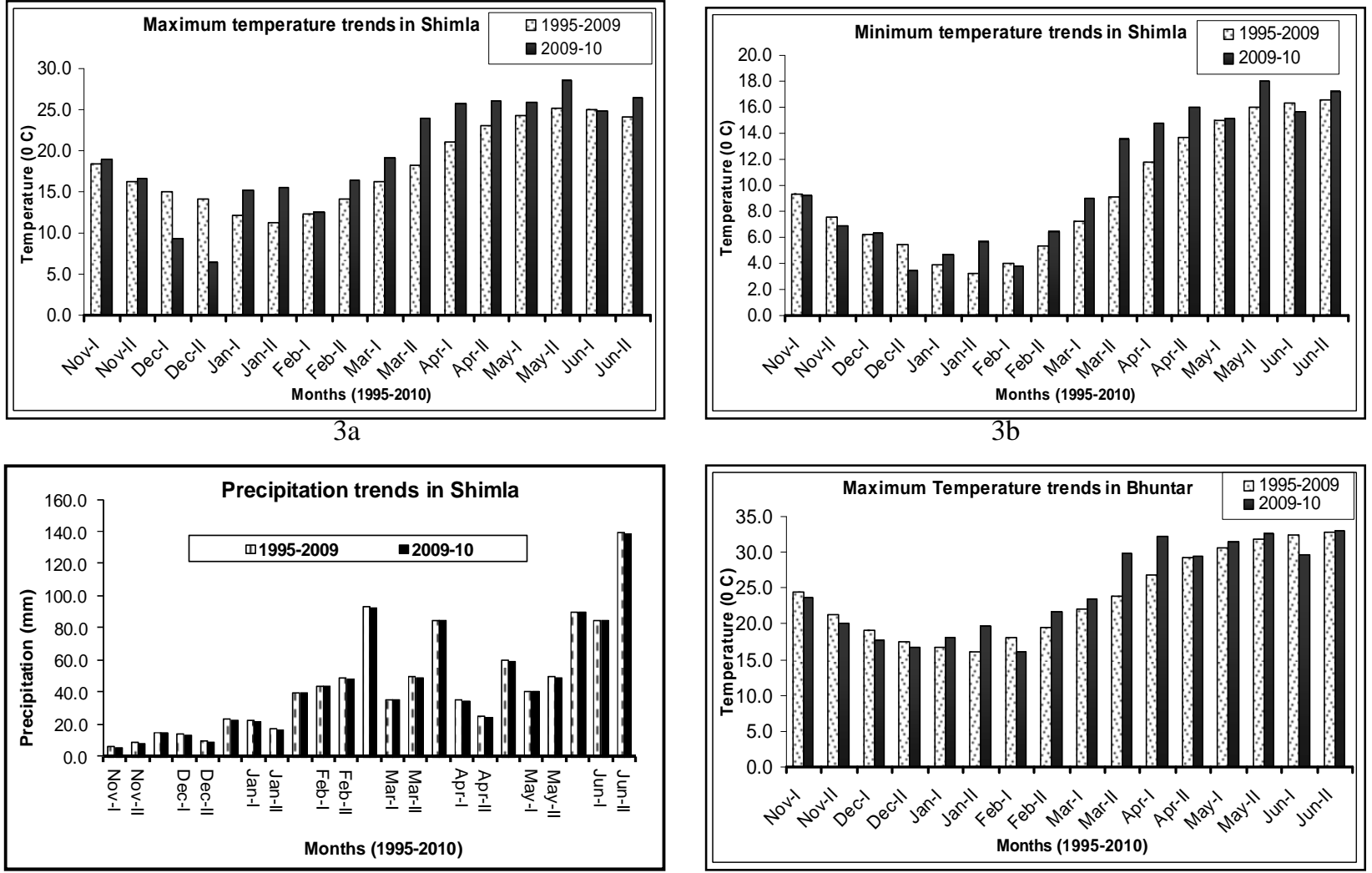

$3 c$

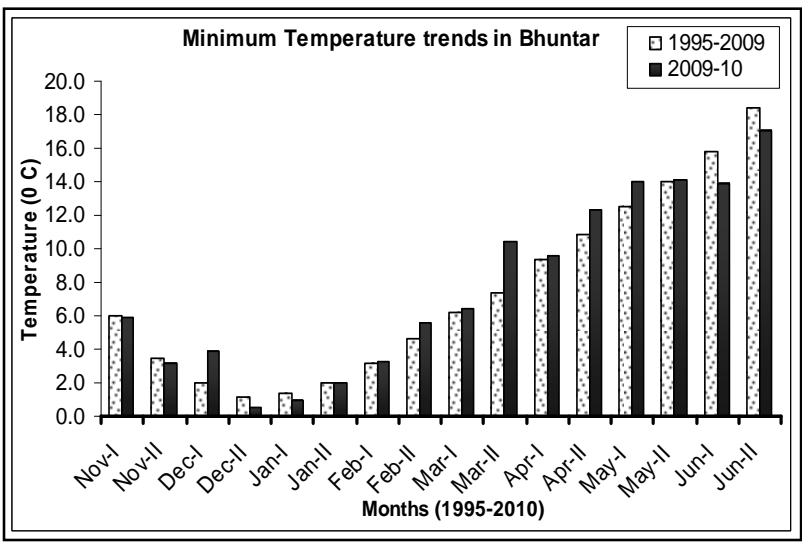

$3 \mathrm{e}$

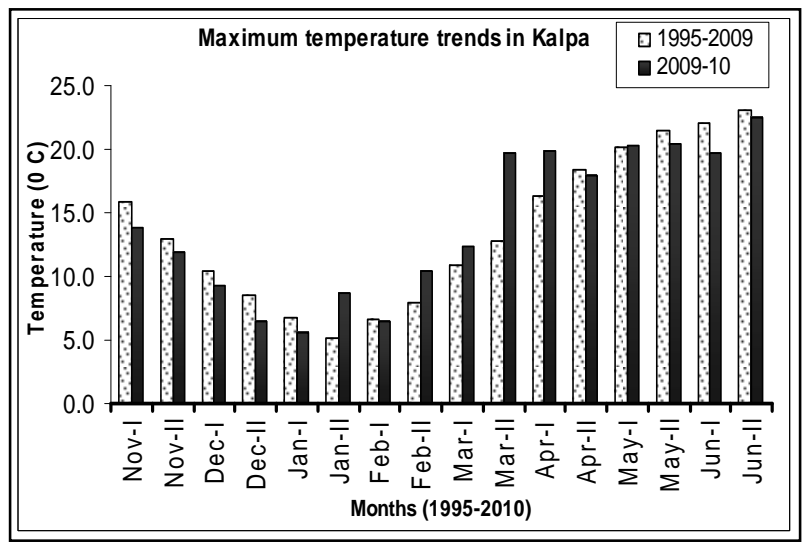

$3 \mathrm{~g}$

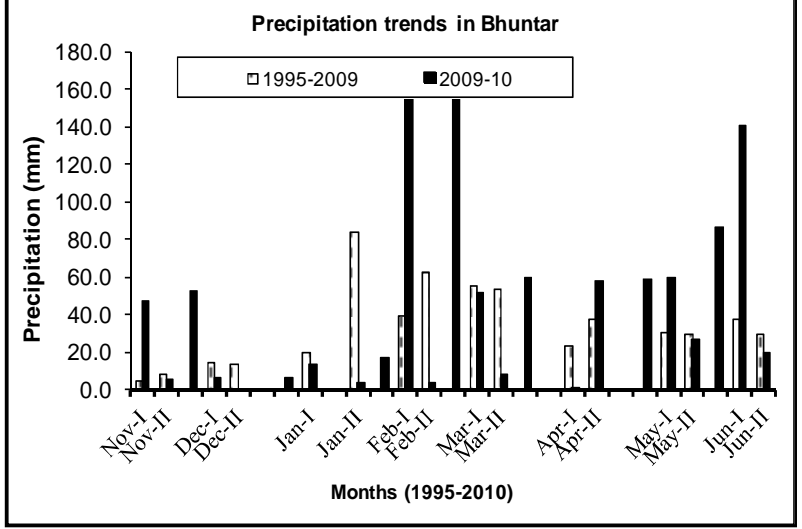

$3 f$

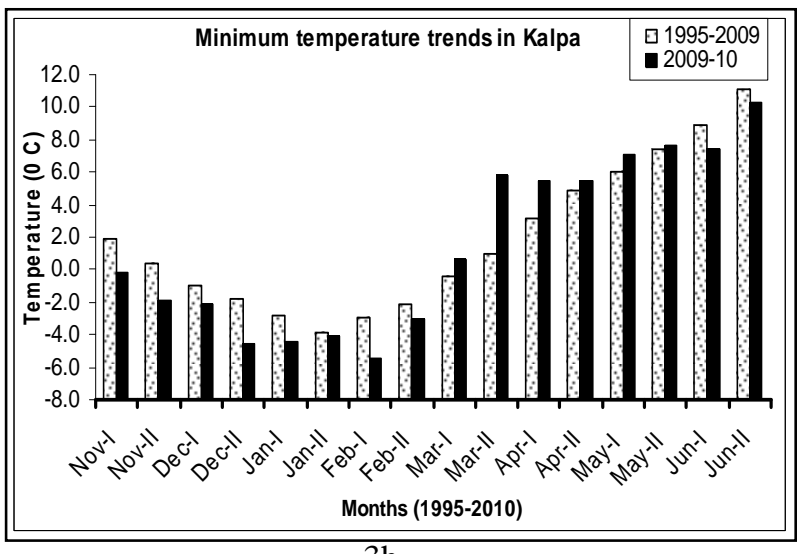




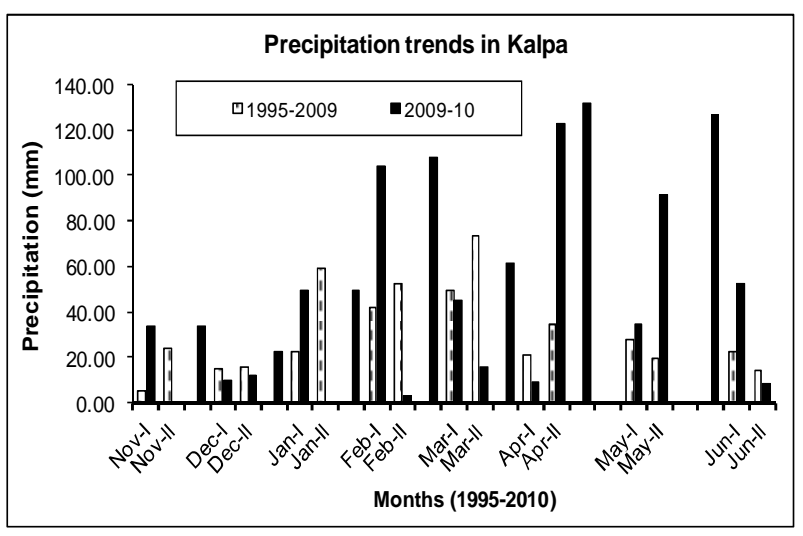

$3 \mathrm{i}$

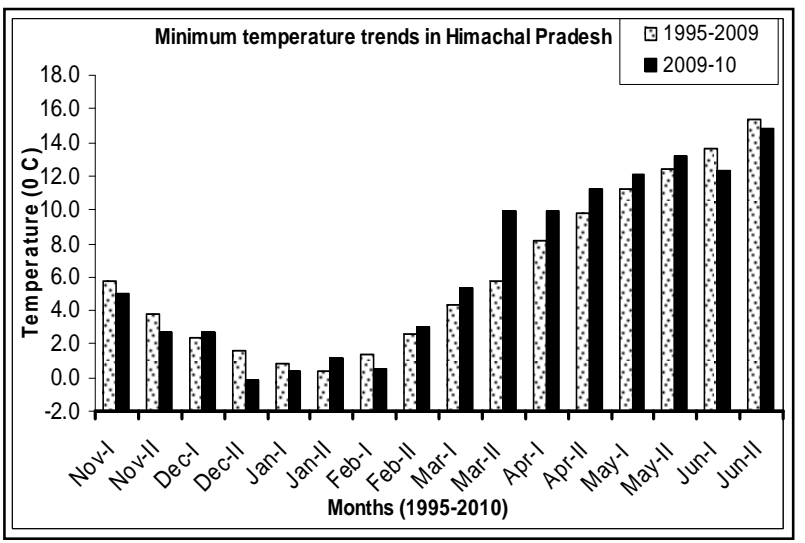

$3 \mathrm{k}$

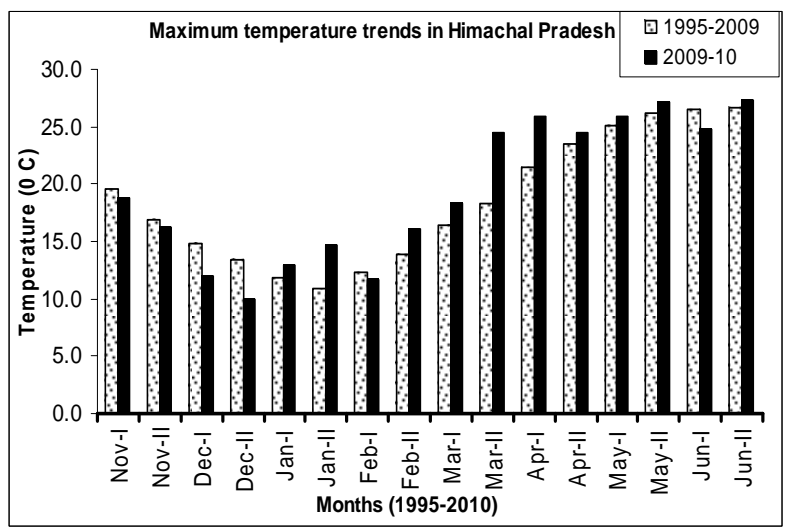

$3 \mathrm{j}$

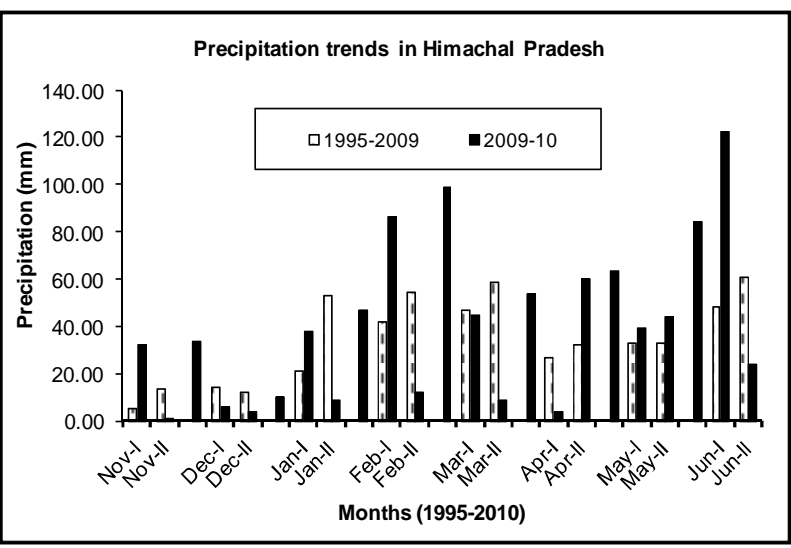

31

Fig.3 a-1 . Weather trends (maximum temperature, minimum temperature and precipitation) in different study sites (Shimla, Kalpa and Bhuntar and H.P.) of Himachal Pradesh (1995-2010).

(Table 1). Rana et al., (2011) also studied the meteorological data for the fruit growing areas of Kullu and found increasing temperature trends during February to April which induced profuse flowering and subsequently the fruit set.

Kalpa region (District Kinnaur): The climate of this region is cold and dry. The maximum temperature in the region remained lower over the past years (19952009) ranging from 5.2 to $13.0^{\circ} \mathrm{C}$ in the pre bloom period. The pre bloom period in the duration of 19952009 was accompanied by a winter precipitation of 105.0 to $345.0 \mathrm{~mm}$ fulfilling the chill requirement. Conversely, a higher precipitation $(521.0$ to $587.0 \mathrm{~mm})$ and low temperature remaining below $12^{\circ} \mathrm{C}$ in the flowering period in some years was obtained. The climate of Kalpa region however, witnessed a slight increase in the temperature since past few years. The maximum temperature in late pre bloom in the year 2009-10 observed between 8.7 to $13.8^{\circ} \mathrm{C}$ which was 1.0 to $2.0^{\circ} \mathrm{C}$ higher than the $1995-2009$. Subsequently, during the bloom period maximum temperature to the tune 17.9 to $19.8^{\circ} \mathrm{C}$ was observed (Fig. $8 \mathrm{~g}$ ) which was also higher by 1.5 to $3.5^{\circ} \mathrm{C}$. The rainfall to the tune of 127.5 to $502.0 \mathrm{~mm}$ was received during pre bloom period of 2009-10 which revealed an increase of 107.8 per cent compared to $1995-2009$. The minimum temperature in 2009-10 revealed a decrease of 1.0 to $2.2^{\circ} \mathrm{C}$ during November and January and an increase of 0.5 to $2.3^{\circ} \mathrm{C}$ during the bloom period as compared to 1995 2009 (Fig. 3h). The rainfall received in flowering period ranged between 163.0 and $453.0 \mathrm{~mm}$ (86.8 per cent higher than 1995-2009) enabled optimal flowering for the region. The minimum temperature during post bloom season was $1.0^{\circ} \mathrm{C}$ higher and maximum temperature remained above $22.0^{\circ} \mathrm{C}\left(0.5^{\circ} \mathrm{C}\right.$ higher $)$ compared to $1995-2009$ followed by 11.5 per cent lesser rainfall of the range of 355.0 to $525.0 \mathrm{~mm}$ ensuing in good fruit size and quality (Fig. 3i). The productivity of Kalpa region indicated a rise in the past decade with highest productivity of $10.03 \mathrm{MT} / \mathrm{ha}$ in the year 200910 (Table 1) due to the beneficial climatic conditions. Verma et al. (2006) evaluated the chill units and productivity relationship for the Kinnaur district and found that the region was becoming more suitable for apple cultivation owing to the increasing trend in temperature.

Weather conditions of Himachal Pradesh: In order to further explicit the climatic conditions affecting the productivity, average weather data of the three apple growing sites for decisive months for chill accumula- 
Table 3. Correlation matrix of productivity with season wise weather parameters of apple growing regions of Himachal Pradesh (1995-2010).

\begin{tabular}{|c|c|c|c|c|c|c|c|c|c|}
\hline \multirow{3}{*}{ Season } & \multicolumn{3}{|c|}{ Shimla } & \multicolumn{3}{|c|}{ Bhuntar } & \multicolumn{3}{|c|}{ Kalpa } \\
\hline & \multicolumn{2}{|c|}{ Temperature } & \multirow{2}{*}{ Rainfall } & \multicolumn{2}{|c|}{ Temperature } & \multirow{2}{*}{ Rainfall } & \multicolumn{2}{|c|}{ Temperature } & \multirow{2}{*}{ Rainfall } \\
\hline & Maximum & $\overline{\text { Minimum }}$ & & Maximum & Minimum & & Maximum & Minimum & \\
\hline $\begin{array}{l}\text { Pre bloom (Nov } \\
\text {-Feb) }\end{array}$ & $-0.46^{*}$ & $-0.50 *$ & -0.08 & $-0.50 *$ & 0.09 & -0.08 & -0.10 & $-0.89 *$ & -0.01 \\
\hline $\begin{array}{l}\text { Bloom (Mar- } \\
\text { Apr) }\end{array}$ & 0.30 & 0.28 & -0.21 & 0.14 & 0.36 & 0.25 & $0.53 *$ & -0.15 & -0.19 \\
\hline $\begin{array}{l}\text { Post bloom } \\
\text { (May-Jun) }\end{array}$ & 0.38 & 0.23 & 0.05 & -0.11 & -0.33 & 0.25 & -0.07 & $-0.50 *$ & -0.04 \\
\hline
\end{tabular}

* significant at 5 percent level of significance

tion, flowering and fruit set in apple for the period of 1995-2010 were studied. The maximum temperature during the pre bloom period oscillated between 11.8 and $19.6^{\circ} \mathrm{C}$ in $1995-2009$. The weather data clearly connoted 13 to 19 per cent decrease in the maximum temperature for the months of November, December, January and February during 2009-10 which was 0.7, $3.1,2.5$ and $0.8^{\circ} \mathrm{C}$ lower compared to $1995-2009$, respectively (Fig. 3j). The analysis indicated decrease of $0.9,0.7,0.3,0.4$ and $0.9^{\circ} \mathrm{C}$ in the minimum temperature of November, December, January, February and March, respectively in 2009-10 (Fig. 3k). The average pre bloom rainfall recorded during 2009-10 (93.5 to $326.3 \mathrm{~mm}$ ) was 39 to 57 per cent higher than 1995 2009 (48.9 to $213.7 \mathrm{~mm}$ ) signifying a sustainable bloom period. The 3 to $4{ }^{\circ} \mathrm{C}$ rise in temperature with 52 per cent higher precipitation of $270.7 \mathrm{~mm}$ during the month of March 2010 compared to last 14 years benefited the crop in establishing profuse flowering and hence a good fruit set. The average maximum temperature during the post bloom period (May-June) in the year 2009-10 remained between 29.0 and $33.0^{\circ} \mathrm{C}$ which was $1.0^{\circ} \mathrm{C}$ higher compared to the previous years. The rise in post bloom temperature was followed by 23 per cent higher amount of rainfall, ranged between 324.0 and $736.0 \mathrm{~mm}$ compared to 1995-2009 resulting in an optimal fruit set, good fruit size and quality (Fig. 31). More and Bhargava (2010) also suggested that low temperature and frost conditions during fruit maturity period can cause sub lethal injury or shriveling of fruits thus causing heavy loss to the crop load. The maximum temperature $\left(18.0\right.$ to $\left.24.5^{\circ} \mathrm{C}\right)$ during bloom period of 2009-10 was in proximity to the year $1998-99\left(17.0\right.$ to $\left.23.3^{\circ} \mathrm{C}\right)$ which was the second highest productive year $(6.85 \mathrm{MT} / \mathrm{ha})$ in the last 15 years. The precipitation also remained moderate during the past 15 years only at some points it was higher as in the year 2004-05.

Rana et al., (2014) indicated from their study that apple and other fruits registered 12.1 and 59.8 per cent higher productivity during heavy snowfall event of 2004-05 in Himachal Pradesh in comparison to 200304 which lowered down the temperature during winter period.

These conditions indicated conclusively the role of different meteorological components during various phenological growth stages on the productivity of apple. Therefore, the increase of 58 per cent in the productivity of the state in the year 2009-10 since last 15 years can be attributed to the favourable climate in this year (Table 2). In an another study it was revealed that minimum temperature of November, January and February and maximum temperature of March and October are most important factor to predict the apple yield in Kullu district of Himachal Pradesh (Sen et al., 2015).

Correlation studies: The correlation was worked out between productivity and the season wise values of weather parameters (Table 3 ). The maximum temperature $(-0.46)$ and minimum temperature $(-0.50)$ in Shimla region during pre bloom period showed a negative and significant correlation with productivity indicating an increase in temperature to negatively impact the productivity. A positive correlation of maximum $(0.30)$ and minimum temperature $(0.28)$ with productivity was obtained for the month of March signifying that a rise in temperature to be beneficial for the productivity. The post bloom period revealed a positive correlation between maximum, minimum temperature and rainfall implying an increase in temperature and rainfall to raise the productivity. The weather parameters of Bhuntar region showed positive correlation between productivity and maximum (0.14) and minimum temperature $(0.36)$, rainfall $(0.25)$ for bloom period and negative correlation for temperature of post bloom period indicating the rise in summer temperature to dwindle the productivity. The productivity of Kalpa region revealed a significant correlation with minimum temperature $(-0.89)$ of pre bloom period. The maximum temperature in bloom period showed a positive and significant correlation (0.53) indicating the growing suitability of the region for apple production. The post bloom period revealed negative correlation with maximum and minimum temperature and rainfall.

\section{Conclusion}

The study clearly revealed that temperature in apple growing regions of Himachal Pradesh remained lower during the chill accumulation period and started rising ( 3 to $4^{\circ} \mathrm{C}$ rise) during the month of March, accompa- 
nied by a good amount of rainfall in bloom and post bloom period of 2009-10 which resulted in overall apposite conditions for profuse flowering, good fruit set and hence contributing to the plenteous productivity compared to 1995-2009. It was realized from the study that the minimum temperature ranged between 0.4 and $4.9^{\circ} \mathrm{C}$, maximum temperature of the range of 10.9 to $16.4^{\circ} \mathrm{C}$ coupled with rainfall to the tune of 93.5 to $326.3 \mathrm{~mm}$ during the pre bloom period. The temperature during bloom ranged between 19.0 and $24.0^{\circ} \mathrm{C}$ and rainfall in the range of 270.0 to $320.0 \mathrm{~mm}$ followed by the post bloom temperature range of 29.0 to $33.0^{\circ} \mathrm{C}$ along with rainfall of 330.0 to $735.0 \mathrm{~mm}$ which were suitable climatic conditions for bumper productivity.

\section{REFERENCES}

Aditya, Rana, R.S., Chauhan, R.C. and Sen V., (2012). Farmers' Perception in relation to Climate Variability in Apple Growing Regions of Kullu District of Himachal Pradesh. Journal of Agricultural Physics, 12(1-2): 1-12.

Anonymous. (2009). Department of Agriculture (DOA). State Agriculture Plan: H.P., Published by Directorate of Agriculture, Government of Himachal Pradesh.Vol. XII.

Anonymous. (2015). Economic Survey of Himachal Pradesh 2014-15. Published by Economics \& Statistics Department. HP Government, Shimla, pp 50.

Awasthi, R. P. (2006). Strategies for improving productivity of temperate fruit crops in India. In: Kishore, D.K., Sharma, S.K., Pramanick, K.K. (eds.), Temperate Horticulture: Current scenario. New India Publishing Agency, New Delhi, pp 193-200.

Byrne, D. H., and Bacon, T. A. (1992). Chilling estimation: its importance and estimation. The Texas Horticulture,
18: 8-9.

More, T. A. and Bhargava, R. (2010). Impact of Climate Change on production of fruit crops in arid regions. In: Singh, H.P., Singh, J.P. and Lal, S.S. (eds.), Challenges of Climate Change- Indian Horticulture. pp 76-84.

Rana, R.S., Singh, M., Upadhyay, S.K. and Sharma, Rohit. (2011). Impact of climatic conditions on temperate fruit crops of Himachal Pradesh. In: Dhillon, W.S., Aulakh, P.S., Singh, Harminder, Gill, P.P.S. and Singh, N.P. (eds.), Climate Change and Fruit Production. pp 162-170.

Rana, R.S., Kalia,V., Bhagat, R.M., Singh, S., Kaushal, A. and Sood K., 2014. Geospatial Mapping and Analysis of Heavy Snowfall Event for Assessing Impacts on Crops in Western Himalaya, In: Compendium cum Abstract, International Symposium on "New- Dimensions in Agro-meteorology for Sustainable Agriculture (NASA-2014)" w.e.f. October 16-18, 2014 at G.B.P.U.A.\&T, Pantnagar, pp 140-141.

Sen, V., Rana, R.S., Chauhan , R.C. and Aditya. (2015). Impact of climate variability on apple production and diversity in Kullu valley, Himachal Pradesh. Indian Journal of Horticulture, 72(1): 14-20.

Singh, M., Kumar, J. and Bhardwaj, S.S. (2009). Rainfall probability during dormant and growing seasons of apple in Himachal Pradesh. Journal of Agrometeorology, 11(1): 47-50.

Vedwan, N. (2006). Culture, Climate and the Environment: Local Knowledge and Perception of Climate Change among Apple Growers in Northwestern India. Journal of Ecological Anthropology, 10: 4-18.

Verma, K .S., Mankotia, M. S., Bhardwaj, D. R., Bhardwaj, S. K., Thakur, C. L. and Thakur, M. (2006). Annual Progress Report of the project "Impact Vulnerability and Adaptation of Mountain Agriculture to Climate Change”, ICAR, New Delhi, India. 